\title{
Analisis Numeris Menggunakan Agent Based Modelling Untuk Evakuasi Bencana Tsunami Gedung I Universitas Bengkulu, Indonesia
}

\author{
Fitria Nabila ${ }^{1}$, Hardiansyah ${ }^{2}$, Lindung Zalbuin Mase $^{3 *}$ \\ 12 Program Studi Teknik Sipil - Fakultas Teknik, Universitas Bengkulu \\ Jl. WR. Supratman, Kandang Limun, Muara BangkaHulu, Kota Bengkulu, (0736) 38119 \\ * Corresponding Author's E-mail: Imase@unib.ac.id
}

\begin{abstract}
ABSTRAK
Penelitian ini dilakukan pada Gedung I, Universitas Bengkulu, yang bertujuan untuk memodelkan pergerakan pengguna gedung dalam melakukan evakuasi tsunami menggunakan Pemodelan Berbasis Agen. Penelitian diawali dengan melakukan survei kendaraan parkir pada halaman Gedung I untuk mendapatkan waktu puncak kendaraan parkir. Selanjutnya dilakukan penyebaran kuesioner untuk mendapatkan informasi perjalanan harian dan ketika proses evakuasi bencana tsunami menuju pintu keluar bagian belakang. Hasil observasi dan kuesioner selanjutnya dianalisis lebih lanjut, khususnya untuk mengetahui validitas data, derajat kejenuhan, volume, kapasitas. Penelitian ini mempertimbangkan beberapa ruas jalan dan rute alternatif. Analisis data menunjukkan kondisi ruas jalan yang ditinjau dari hasil permodelan konsisten dengan hasil pengamatan langsung di lapangan. Secara umum, Rute alternatif evakuasi yang banyak dipilih responden adalah rute yang sering dilalui pada waktu harian dan akses yang mudah pada saat evakuasi. Hasil penelitian juga menunjukkan bahwa nilai derajat kejenuhan pada R01 (0,1598) serta kapasitas R07 dan R08 yang tinggi sebesar 2039,59 skr/jam. Ini mengindikasikan bahwa perlu adanya pengembangan kinerja jaringan jalan lokal. Ini dapat menjadi rekomendasi dalam memudahkan proses evakuasi tsunami.
\end{abstract}

Kata Kunci: Permodelan, Ruas Jalan, Rute Alternatif, Evakuasi.

\begin{abstract}
This study was conducted at Gedung I, Universitas Bengkulu, which aims to model the movement of building users in conducting tsunami evacuations using Agent Based Modelling. This study initiates by performing the vehicles parking survey at Gedung I to obtain the peak parking period. Furthermore, the questionnaire was distributed to get daily - frequently to information and when the tsunami disaster evacuation process to the rear exit. The observation results and questionnaires were further analyzed, especially to find out the data validity, degree of saturation, volume, and capacity. This study considers road section and alternative routes. Data analysis shows that the condition of the road sections viewed from the results of the modelling is consistent with the result of direct observations in the field. In general, the alternative evacuation routes that many respondents choose are the routes that are often traveled on a daily basis and easy access at the time of evacuation. The results also showed that the value of degree saturation at R01 (0,1598) and high capacity at R07 and R08 was 20399,59 pce/hour. It indicates that there is a need to improve the performance of the local road network. This can be a recommendation in facilitating the tsunami evacuation process.
\end{abstract}

Key Word: Modelling, Road Section, Alternative Routes, Evacuations.

\section{PENDAHULUAN}

Kepulauan Indonesia berada pada jalur subduksi, yang terdapat pada batas antar lempeng bumi. Wilayah Pulau Sumatera dilalui oleh patahan pemicu terjadinya gempa bumi. Bengkulu berbatasan dengan Samudera Hindia di sebelah barat, yang terdapat perpotongan lempeng yang menyebabkan Bengkulu menjadi rawan gempa dan ancaman tsunami.

Universitas Bengkulu (UNIB) terletak pada pesisir pantai, sehingga menjadi pengaruh besar ketika terjadi ancaman bencana tsunami. Oleh karena itu perlu dilakukan penelitian terhadap kinerja jalan lokal Universitas Bengkulu terhadap aktivitas Pengguna Gedung I Universitas Bengkulu menggunakan pemodelan berbasis agen (Agent Based Modelling). Pemodelan evakuasi memahami perilaku individu sebagai agen pemodelan dengan menggunakan aplikasi NetLogo.

Penelitian ini menggambarkan agen sebagai pengguna Gedung I untuk mengetahui respons pengguna Gedung I Universitas Bengkulu saat evakuasi di tiap ruas jalan lokal universitas. Selain itu, penelitian ini untuk mengetahui rute tinjauan yang banyak dipilih oleh pengguna Gedung I Universitas Bengkulu. Rute jaringan jalan yang dipilih adalah 4 rute jaringan jalan terpendek menuju pintu keluar Universitas Bengkulu bagian Belakang.

Adanya penelitian ini diharapkan dapat mengembangkan kinerja jaringan jalan lokal universitas yang ditinjau dalam pemodelan. Penelitian menghitung waktu tempuh dan ruas jalan alternatif yang digunakan pengguna Gedung I melakukan evakuasi, berdasarkan kapasitas dan derajat kejenuhan. 


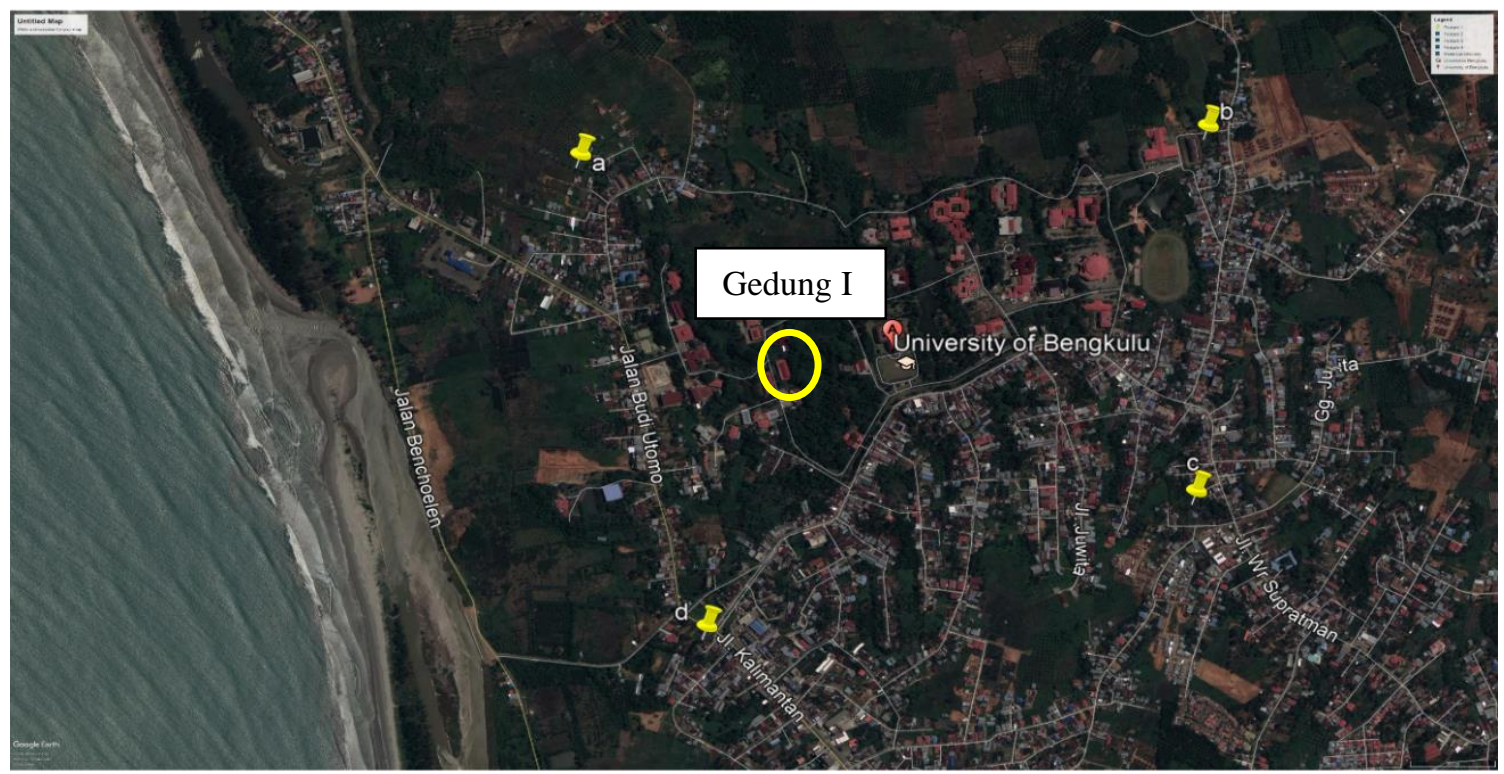

Gambar 1. Lokasi Penelitian (dimodifikasi dari Google Earth, Zona Universitas Bengkulu 2019)

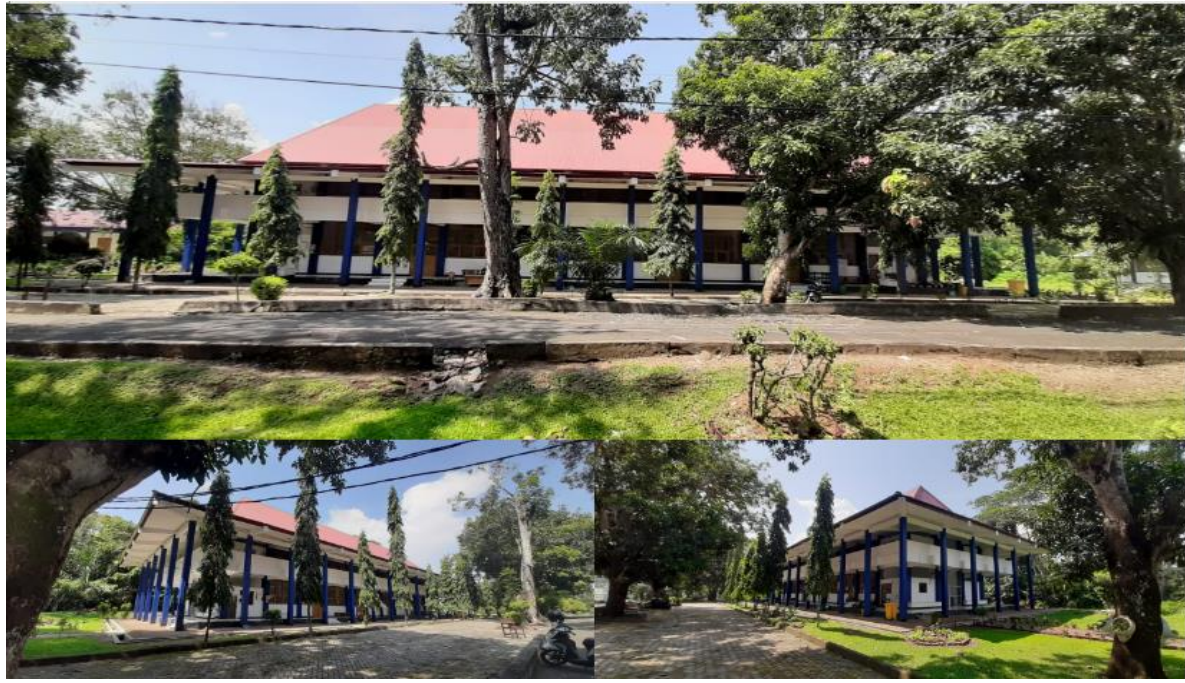

Gambar 2. Gedung I (Survei Langsung)

\section{TINJAUAN PUSTAKA}

\subsection{Sejarah Gempa dan Tsunami di Bengkulu}

Provinsi Bengkulu berbatasan langsung dengan Samudera Indonesia pada garis pantai sepanjang $\pm 433 \mathrm{~km}$. Terjadinya tsunami besar pada 26 Desember 2004, daerah Aceh dan Nias adalah wilayah di Indonesia yang paling parah terkena dampaknya. Hal ini dikarenakan wilayah tersebut berada pada daerah pembangkit tsunami yaitu gempa tektonik di wilayah Pulau Simeulue. Berdasarkan kondisi ini, pemerintahan memberikan perhatian lebih terhadap kemungkinan terjadinya tsunami di wilayah Provinsi Bengkulu, dengan memperkirakan daerah yang memiliki kemungkinan terkena dampak tsunami melalui pemodelan tsunami yang dapat dibuat. Pemodelan ini dilakukan melalui pertimbangan atas terjadinya gempa besar yang pernah terjadi di wilayah Bengkulu. Berdasarkan data yang ada, Kota Bengkulu telah terjadi terjangan gelombang akibat pergerakan lempeng secara mendadak. Kejadian ini terjadi pada tahun 1797 dan tahun 1833 diawali dengan terjadinya gempa di dasar laut Samudera Hindia [2].

\subsection{Sistem dan Sarana ketika Evakuasi Bencana Tsunami}

Evakuasi dapat dilakukan dengan dua cara yaitu, evakuasi horizontal dan evakuasi vertikal. Evakuasi horizontal diperlukan dengan pertimbangan masyarakat harus melakukan evakuasi menggunakan kendaraan atau berjalan kaki. Evakuasi vertikal dilakukan dengan penggunaan shelter atau bangunan bertingkat tahan gempa. Rute Evakuasi adalah jalan yang akan memandu masyarakat aman ketika evakuasi [12]. 


\subsection{Kinerja Jaringan Jalan}

Kinerja jalan adalah suatu pengukuran secara kuantitatif dalam menggambarkan kondisi pada suatu rua jalan. Ketika menganalisis suatu kinerja jaringan jalan, pada umumnya membahas tentang kapasitas, derajat kejenuhan atau Volume Capacity Ratio (VCR), kecepatan rata - rata, waktu perjalanan, tundaan dan antrean. Sedangkan untuk pengukuran secara kualitatif yang menggambarkan keadaan operasional dalam arus lalu lintas dan persepsi pengemudi tentang kualitas berkendara dinyatakan dengan tingkat pelayanan ruas jalan [5].

Menurut Pedoman Kapasitas Jalan Indonesia atau PKJI (2014) [11] bahwa kapasitas merupakan arus lalu lintas maksimum dalam satuan skr/jam yang dapat dipertahankan sepanjang segmen jalan tertentu dalam kondisi tertentu, yang melingkupi geometrik, lingkungan dan lalu lintas. Persamaan dasar untuk menentukan kapasitas adalah sebagai berikut:

$$
C=C_{0} x F C_{L J} x F C_{P A} x F C_{H S} x F C_{U K}
$$

Keterangan :

C : kapasitas (skr/jam)

$C_{0} \quad:$ kapasitas dasar $(\mathrm{skr} / \mathrm{jam})$

$F C_{L J} \quad$ : faktor penyesuaian kapasitas terkait lebar lajur /jalur lalu lintas

$F C_{P A}$ : faktor penyesuaian kapasitas terkait pemisah arah, hanya pada jalan tak terbagi

$F C_{H S}$ : faktor penyesuaian kapasitas terkait KHS pada jalan berbahu

$F C_{U K} \quad$ : faktor penyesuaian kapasitas terkait ukuran kota

Pedoman Kapasitas Jalan Indonesia (2014) [11] menyatakan bahwa DJ (Volume Capacity Ratio) adalah ukuran utama yang digunakan untuk menentukan tingkat kinerja segmen jalan. Derajat Kejenuhan ( $\left.D_{J}\right)$ dihitung menggunakan persamaan:

$$
D_{J}=Q / C
$$

Keterangan :

$\begin{array}{ll}\mathrm{D}_{\mathrm{J}} & : \text { Derajat Kejenuhan } \\ \mathrm{Q} & : \text { Arus lalu lintas }(\mathrm{skr} / \mathrm{jam}) \\ \mathrm{C} & : \text { Kapasitas }(\mathrm{skr} / \mathrm{jam})\end{array}$

Menurut MKJI (1997) [7] , jika VCR $\leq 0,75$ masih dalam kategori kejenuhan yang normal. Jika VCR > 0,75 maka ruas jalan atau simpang tidak dapat memberikan kapasitas yang mencukupi bagi pengguna jalan.

\subsection{Pemodelan Transportasi untuk Evakuasi}

Transportasi dalam evakuasi yang berbasis kinerja jaringan jalan memiliki keuntungan dapat modelkan pergerakan lalu lintas ketika evakuasi dalam skala besar. Hasil yang diperoleh berupa waktu evakuasi dan jalur yang padat atau rentan ketika dilakukan pengungsian. Diterapkannya pemodelan evakuasi yang berdasarkan kinerja jaringan jalan dapat membantu pengoptimalan rute evakuasi yang digunakan oleh pengungsi [4].

\subsection{Pemodelan Berbasis Agent Based Modelling menggunakan NetLogo}

Bonabeau [1] menyatakan bahwa dalam ABM suatu sistem dimodelkan dengan kumpulan entitas atau objek yang dapat mengambil keputusan secara otonom, entitas ini disebut agen. Setiap agen bertindak menanggapi respons terhadap bencana dengan menyesuaikan terhadap lingkungannya. Pemodelan berbasis agen atau Agent Based Modelling (ABM) yaitu pendekatan pemodelan dalam menganalisis sistem secara kompleks dengan dunia nyata [10].

Model berbasis agen dengan melakukan pendekatan bahwa setiap agen dimodelkan dan dilakukan pengambilan keputusan. Setiap agen melaksanakan peraturan sesuai dengan sistem, dengan demikian agen mampu menjalankan berbagai perilaku masing-masing individu merupakan cerminan dari penduduk yang dievakuasi yang selanjutnya keinginan penduduk untuk evakuasi menjadi salah satu indikator yang digunakan dalam evakuasi. Ancaman bencana yang semakin meningkat menuntut untuk mengembangkan model evakuasi, agar memberikan gagasan untuk penyelamatan masyarakat [4].

\subsection{Instrumen Penelitian (Skala Likert)}

Skala likert memiliki 4 atau lebih butir pertanyaan yang akan dikombinasikan sehingga membentuk suatu skor atau nilai yang dapat mencerminkan pemahaman, perilaku, sikap serta sifat individu [6]. Pemberian skor (Tabel 1) yang digunakan dalam kuesioner penelitian ini adalah teknik Skala Likert. Indikator dalam skala likert dijadikan untuk menyusun item-item instrumen yang dapat berupa pernyataan atau pernyataan. Skala likert digunakan untuk mengukur sikap, pendapat, dan persepsi seseorang atau sekelompok orang tentang fenomena sosial [13]. 


\begin{tabular}{ccc}
\multicolumn{3}{c}{ Tabel 1. Rentang Nilai Likert Skala 4 } \\
\hline Tipe & Skor & Skala Skor \\
\hline Sangat Tahu & 4 & 3 \\
Tahu & 3 & $2-2,99$ \\
Tidak Tahu & 2 & $1-1,99$ \\
Sangat Tidak Tahu & 1 & $0-0,99$ \\
\hline
\end{tabular}

\subsection{Populasi dan Sampel}

Menentukan jumlah sampel dapat menggunakan rumus untuk menentukan besaran sampel dalam penelitian yaitu Persamaan Slovin sebagai berikut:

$$
n \quad=\frac{\mathrm{N}}{1+\mathrm{N}\left(\mathrm{e}^{2}\right)}
$$

Keterangan :

$$
\begin{array}{ll}
\mathrm{n} & \text { : Jumlah responden } \\
\mathrm{N} & \text { : Jumlah populasi } \\
\mathrm{e} & \text { : persentase kelonggaran karena } \\
& \text { kesalahan pengambilan sampel }
\end{array}
$$

\subsection{Uji Validitas Perbandingan Hasil Kuisioner dan Simulasi NetLogo}

Regresi linier adalah teknik yang digunakan untuk mendapatkan model hubungan antara satu variabel terikat dan satu atau lebih variabel bebas [3]. Untuk pengujian validitas dilakukan perbandingan jumlah agen yang melalui tiap ruas jalan tinjauan berdasarkan hasil kuesioner dan simulasi NetLogo. Analisis regresi linier sederhana adalah hubungan secara linier antara satu variabel independen $(\mathrm{X})$ dengan variabel dependen $(\mathrm{Y}) . b_{0}$ adalah perpotongan atau suatu konstanta yang menyatakan jarak dari titik pangkal ke Titik Potong Garis Sumbu Y.

Rumus yang digunakan antara lain:

$$
\begin{aligned}
& a=\frac{\left(\sum Y_{i}\right)\left(\sum X_{i}^{2}\right)-\left(\sum X_{i}\right)\left(\sum X_{i} Y_{i}\right)}{n \sum X_{i}^{2}-\left(\sum X_{i}\right)^{2}} \\
& b=\frac{n \sum X_{i} Y_{i}-\left(\sum X_{i}\right)\left(\sum Y_{i}\right)}{n \sum X_{i}^{2}-\left(\sum X_{i}\right)^{2}} \\
& r=\frac{n \sum X_{i} Y_{i}-\left(\sum X_{i}\right)\left(\sum Y_{i}\right)}{\sqrt{\left\{n \sum X_{i}^{2}-\left(\sum X_{i}\right)^{2}\right\}\left\{\mathrm{n} \sum Y_{i}^{2}-\left(\sum Y_{i}\right)^{2}\right\}}}
\end{aligned}
$$

Keterangan :

Y : Garis regresi

a : Konstanta, berpotong sumbu vertikal

b : Konstanta regresi

$\mathrm{X}$ : Variabel bebas

n : Jumlah data

$\mathrm{r}$ : Nilai regresi linier

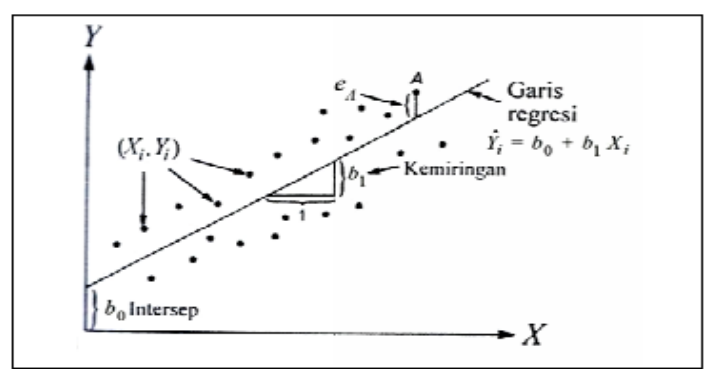

Gambar 3. Grafik Regresi Linier (sumber: Harlan, 2018) 


\section{METODE PENELITIAN}

Penelitian dilaksanakan di lokasi Gedung I dan ruas jalan lokal yang di tinjau pada Universitas Bengkulu. Data yang dikumpulkan pada penelitian ini yaitu data primer dan data sekunder. Metode penelitian dapat dilihat pada bagan alir di bawah ini (Gambar 4).

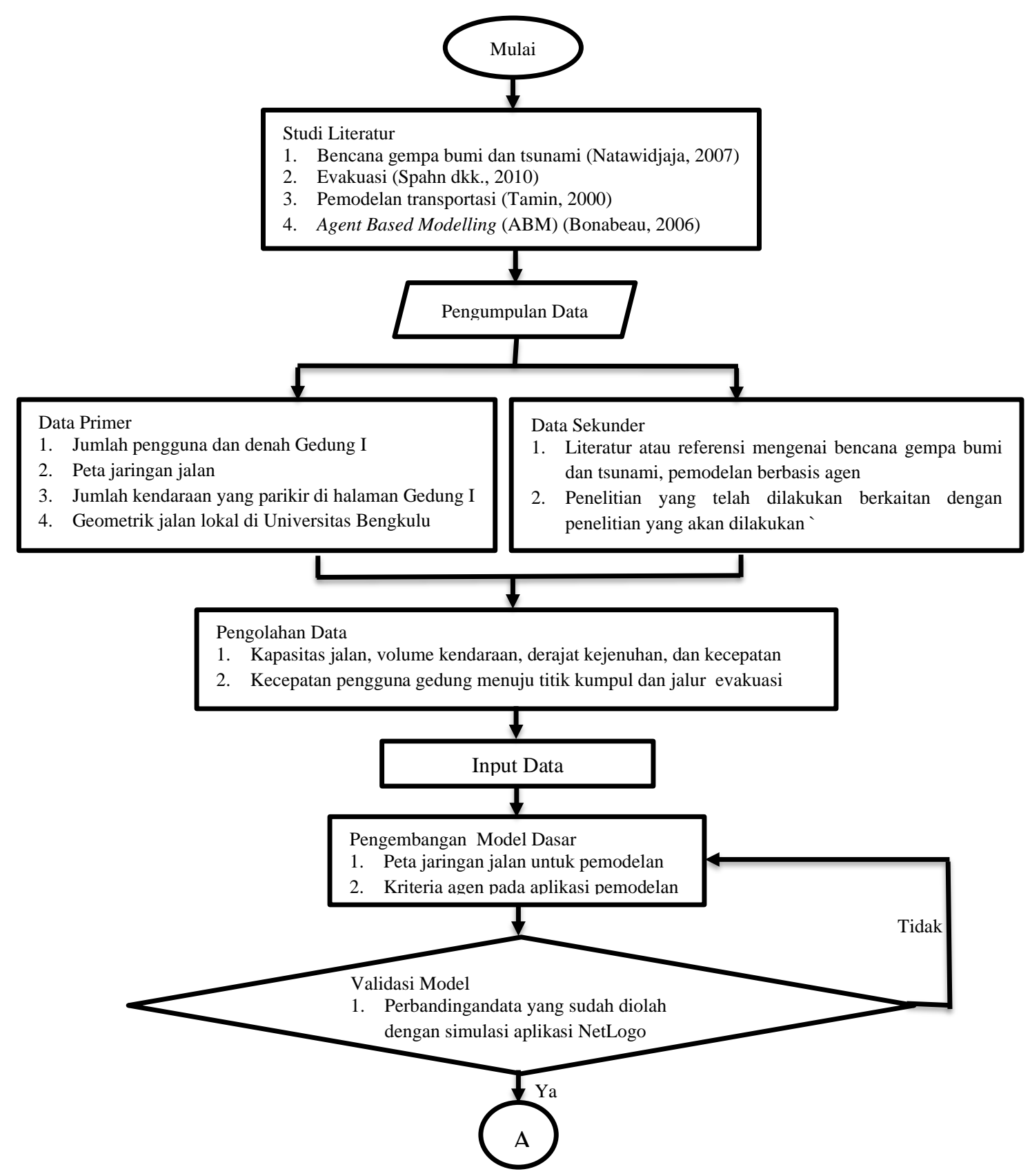

Gambar 4. Bagan Alir Sambungan 


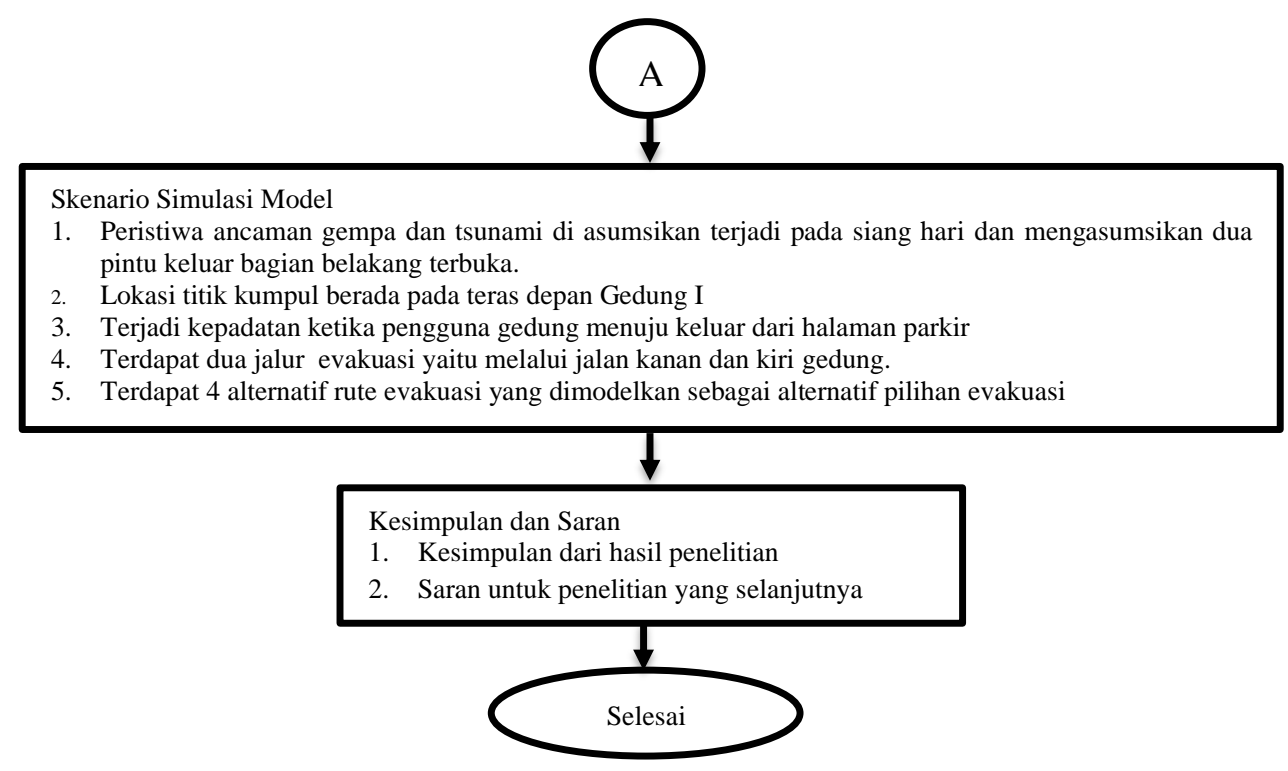

Gambar 5. Bagan Alir Lanjutan

\section{HASIL DAN PEMBAHASAN}

\subsection{Jumlah Pengungsi Gedung I}

Survei yang telah dilaksanakan menunjukkan bahwa persentase pengguna Gedung I $48 \%$ laki - laki dan $52 \%$ perempuan. Persentase (Gambar 6) tersebut mengindikasikan bahwa dari total pengguna gedung sebanyak 650 orang, menunjukkan bahwa 311 orang terdiri dari laki - laki dan 399 orang perempuan.

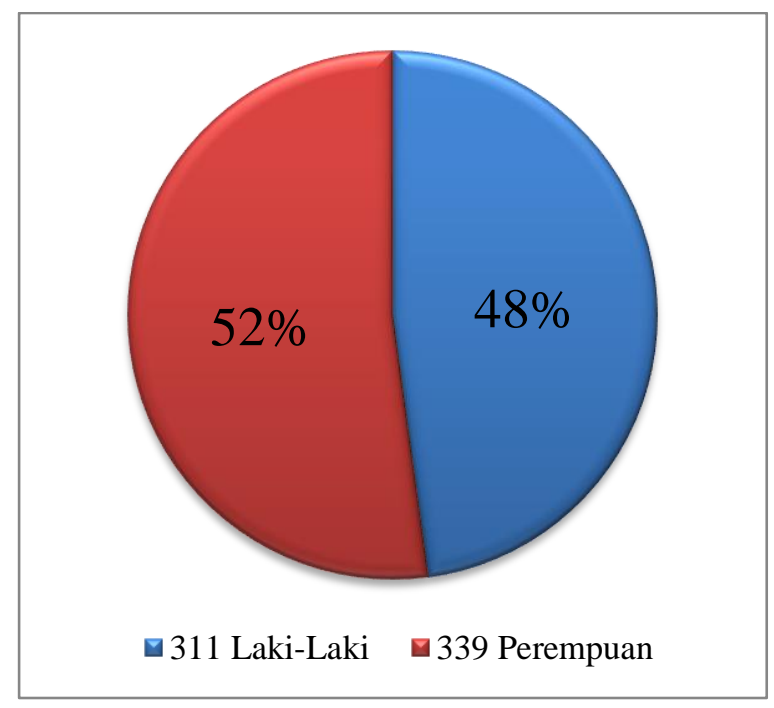

Gambar 6. Jumlah Pengguna Gedung I

\subsection{Survei Parkir}

Moda transportasi yang terdapat di Gedung I Universitas Bengkulu terdiri dari sepeda motor dan kendaraan ringan. Letak parkir Gedung I Universitas Bengkulu berada di halaman depan gedung dan sebelah kanan gedung. Halaman parkir pada Gedung I dibedakan menjadi dua yaitu, halaman parkir khusus sepeda motor dan kendaraan ringan. Survei parkir dilaksanakan untuk mengetahui waktu puncak kendaraan parkir pada Gedung I. Dari waktu puncak akan diasumsikan pukul $10.00-11.00$ WIB sebagai waktu terjadinya ancaman bencana tsunami di kawasan Universitas Bengkulu.

\subsection{Jaringan Jalan Universitas}

Jaringan jalan yang dianalisis terdapat 9 ruas jalan lokal Universitas Bengkulu. Ruas jalan yang ditinjau akan dilalui pengguna Gedung I seperti terdapat pada Gambar 7. Sembilan ruas jalan diberi nama berdasarkan penomoran yaitu, dari R01 sampai R09. Dikarenakan belum terdapatnya nama pada tiap jalan lokal Universitas Bengkulu. 
Sembilan ruas jalan dimodelkan menjadi 4 rute alternatif tinjauan ketika melakukan evakuasi. Rute alternatif yang ditinjau nantinya akan dipilih melalui kuesioner oleh pengguna Gedung I ketika melakukan evakuasi. Empat rute alternatif tersebut dapat dilihat pada Gambar 8.

Keterangan 4 rute jalan tinjauan:

1. Rute 1 terdiri dari ruas R01, R02, R05, dan R06 dengan total panjang 850,5 m

2. Rute 2 terdiri dari ruas R01, R02, R05, R08, dan R09 dengan total panjang 1.194,8 m

3. Rute 3 terdiri dari ruas R01, R04, dan R07 dengan total panjang 859,9,

4. Rute 4 terdiri dari ruas R03 dan R07 dengan total panjang 833,4 m

Keterangan 9 ruas jalan yang ditinjau:

1. $\mathrm{R} 01$ = Ruas jalan pada sisi kanan gedung, menuju pertigaan belakang sepanjang $244,3 \mathrm{~m}$

2. R02 = Ruas jalan dari pertigaan belakang rektorat menuju GB 2 melalui danau sepanjang $360 \mathrm{~m}$

3. R03 = Ruas Jalan dari Gedung I (pada bagian kiri) melalui Gedung UPT menuju persimpangan di halaman depan Rektorat sepanjang $493 \mathrm{~m}$

4. $\mathrm{R} 04$ = Ruas jalan pada sisi kanan rektorat $275,2 \mathrm{~m}$

5. $\mathrm{R} 05$ = Ruas jalan dari GB 2 sampai Gedung LPTIK sepanjang $147,7 \mathrm{~m}$

6. R06 = Ruas jalan dari LPTIK menuju Pintu keluar 1 (Dekanat FISIP) sepanjang 98,5 m

7. $\mathrm{R} 07$ = Ruas jalan dari depan Gedung Rektorat menuju pintu keluar 1 (Melalui Dekanat FISIP) sepanjang $340,4 \mathrm{~m}$

8. $\mathrm{R} 08$ = Ruas jalan dari LPTIK sampai Dekanat Teknik (Melalui GSG) sepanjang $275 \mathrm{~m}$

9. $\mathrm{R} 09$ = Ruas jalan dari Dekanat Teknik menuju pintu keluar 2 sepanjang 167,8 $\mathrm{m}$
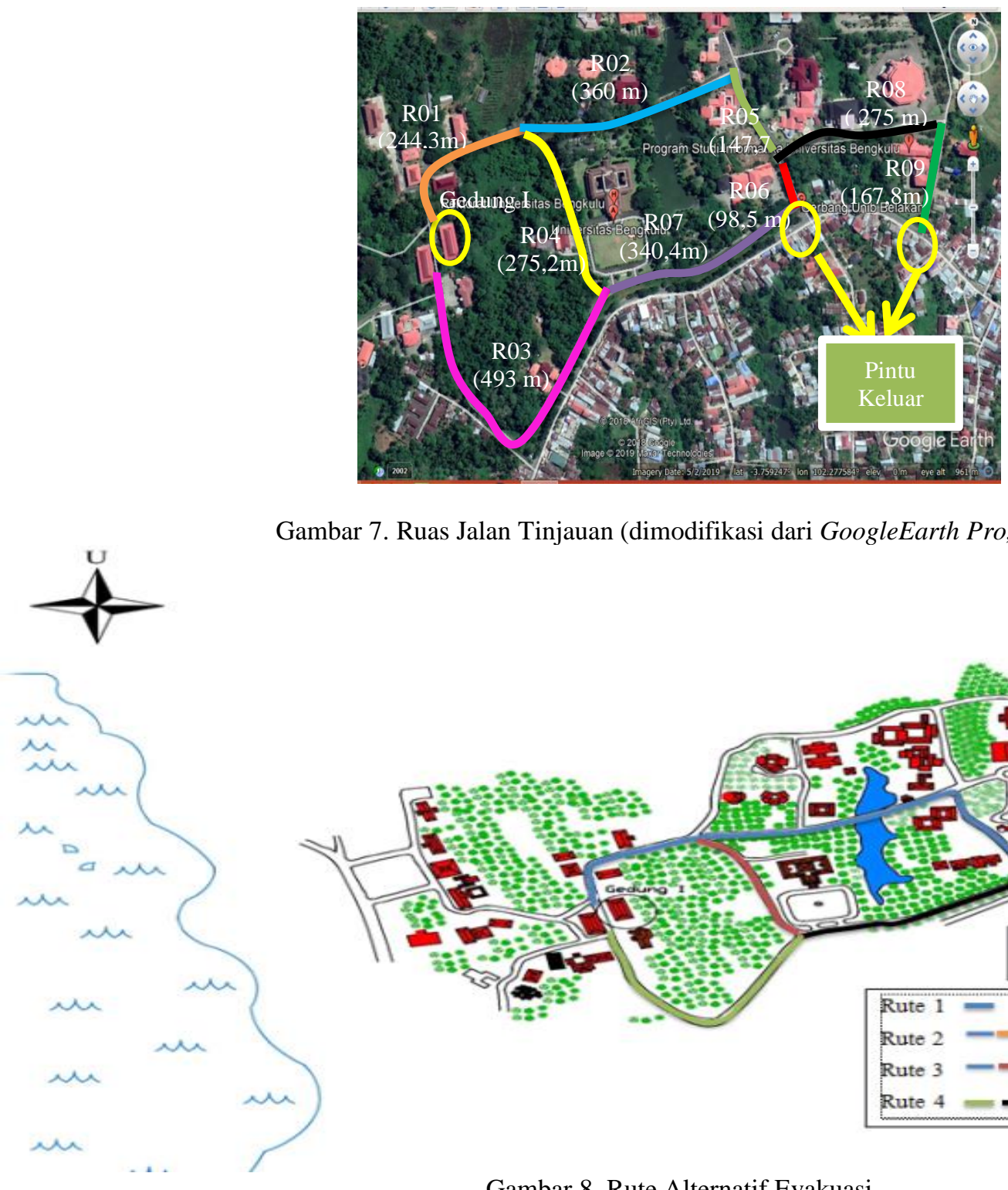

Gambar 7. Ruas Jalan Tinjauan (dimodifikasi dari GoogleEarth Pro, 2019)

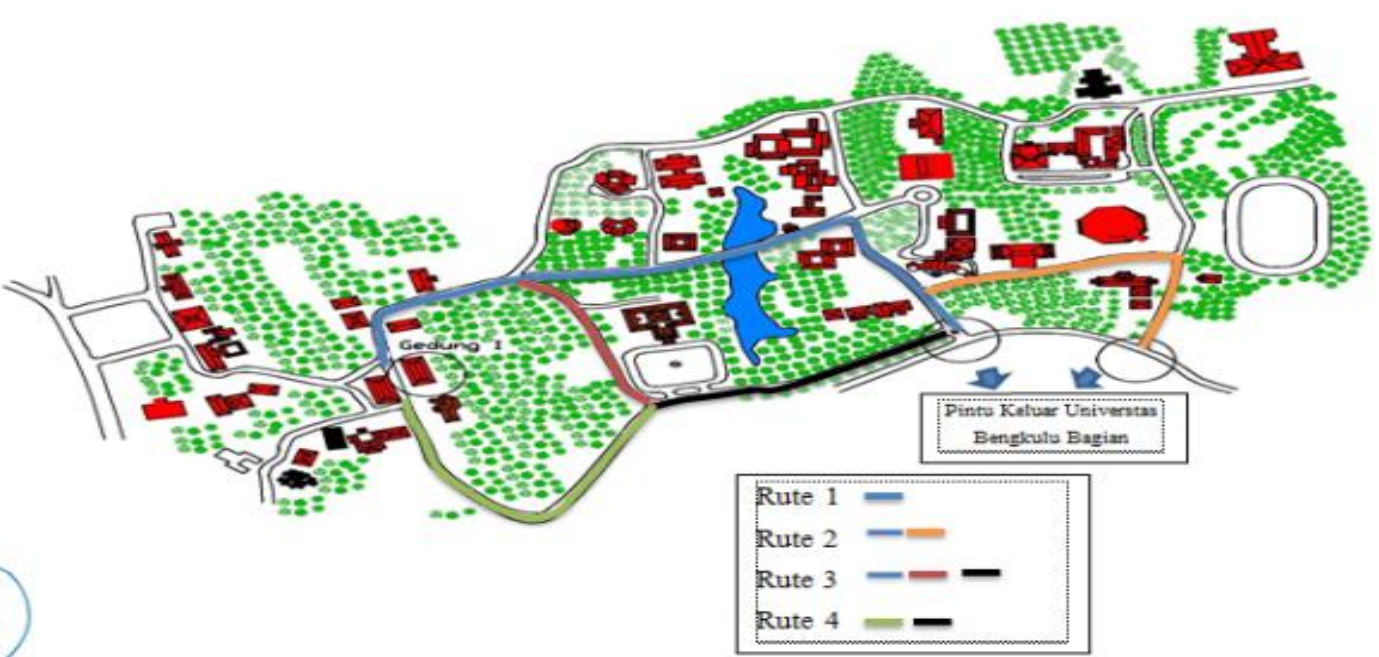

Gambar 8. Rute Alternatif Evakuasi 


\subsection{Hasil Percobaan}

Hasil percobaan dilakukan dengan memodelkan agen pada NetLogo dengan melakukan perbandingan regresi linier sederhana menggambarkan kedekatan dari output NetLogo dengan hasil kuesioner. Tampilan pemodelan pada NetLogo dapat dilihat pada Gambar 9. Data kuesioner yang diperlukan adalah pilihan rute evakuasi bagi pengguna Gedung I. Jumlah kendaraan parkir diperlukan untuk menentukan waktu puncak penuhnya kendaraan parkir, untuk mengasumsikan waktu terjadi tsunami. Hasil survei parkir menunjukkan pukul 10.00-11.00 WIB adalah waktu puncak padatnya kendaraan di halaman parkir Gedung I Universitas Bengkulu.

Output pada simulasi berulang yang telah dilakukan diambil rata-rata nilai guna mendapatkan nilai terbaik. Maka, rata-rata agent yang melalui ruas jalan dalam bentuk koma akan dilakukan pembulatan. Percobaan yang dilakukan berulang sebanyak 307 menggunakan behavior space running.

Penentuan jumlah sampel percobaan menggunakan tabel Isaac dan Michael dengan persen keyakinan sebesar 5\% sehingga didapat 307 percobaan. Rata-rata agen yang meninggalkan kawasan universitas sebanyak 611 orang/agen. Keseluruhan jumlah agen pada pemodelan sebanyak 650 orang -611 orang $=39$ orang/agen yang diasumsikan gagal ketika melakukan evakuasi. Rekapitulasi penggunaan moda kendaraan ketika evakuasi dapat dilihat pada Gambar 10.

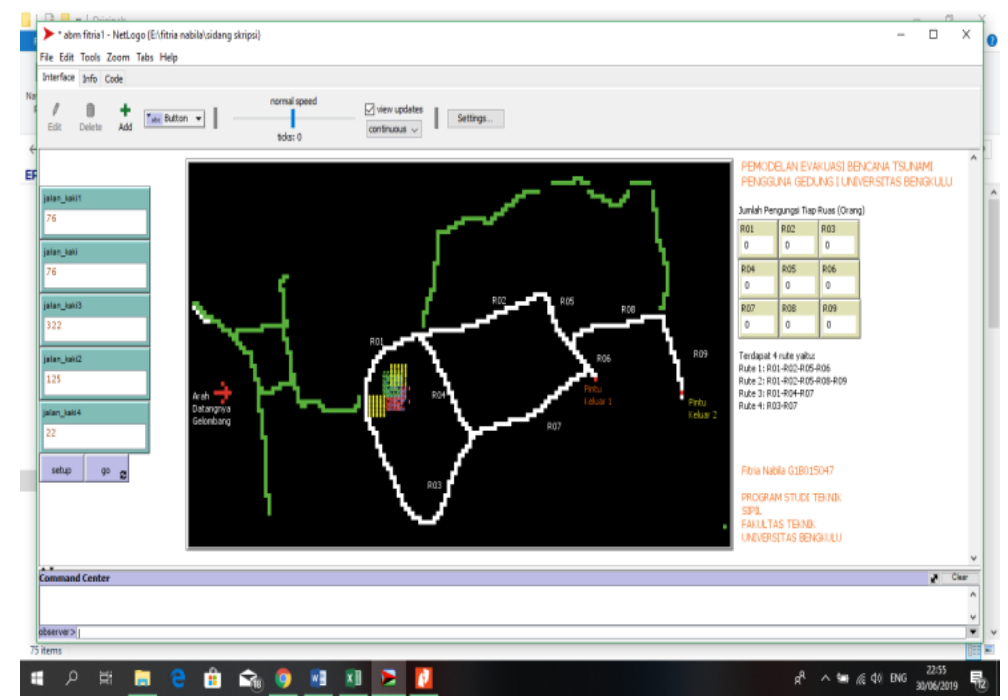

Gambar 9. Tampilan Pemodelan pada NetLogo

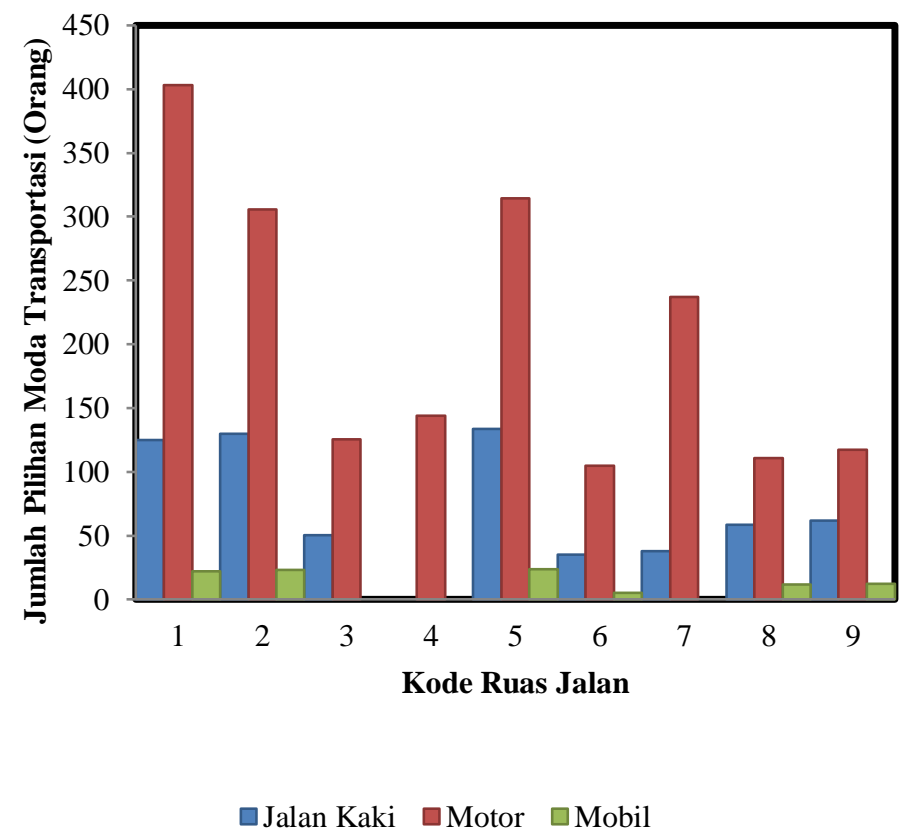

Gambar 10. Diagram Perjalanan Evakuasi dalam Pemodelan 


\subsection{Analisis Kinerja Jalan dalam Pemodelan}

Simulasi dilakukan dengan menjadikan 1 agent di keadaan sebenarnya sama dengan 1 agent pada saat simulasi. Hasil dari simulasi yang dibangun menunjukkan jumlah perjalanan pengungsi akibat bencana tsunami. Jumlah pengungsi yang melalui ruas jaringan jalan perlu dilakukan konversi ke dalam satuan kendaraan ringan (skr). Dalam menghitung kapasitas ruas jalan, dibutuhkan data geometrik dari ruas jalan yang akan ditinjau.

Analisis hasil permodelan yang telah dibangun mendapatkan derajat kejenuhan di setiap ruas jalan tinjauan yang dilalui pengungsi Gedung I Universitas Bengkulu, terdapat 9 ruas jalan alternatif yang digunakan sebagai rute evakuasi oleh pengguna Gedung I. Perbandingan data jumlah (Tabel 3) agen pada kuesioner dan simulasi NetLogo yang menempati ruas jalan yaitu $\mathrm{R}^{2}$ $=0,905$ atau $90,5 \%$. Hasil tersebut menunjukkan lebih dari $70 \%$ data pada kuesioner dan simulasi NetLogo memiliki kemiripan sesuai dengan kriteria validasi yang dibutuhkan (Gambar 11).

Tabel 2. Data Geometrik Ruas Jalan

\begin{tabular}{lcccc}
\hline No & $\begin{array}{c}\text { Kode } \\
\text { Jalan }\end{array}$ & Tipe Jalan & $\begin{array}{c}\text { Lebar } \\
\text { Jalan } \\
(\mathrm{m})\end{array}$ & $\begin{array}{c}\text { Lebar } \\
\text { Bahu }(\mathrm{m})\end{array}$ \\
\hline $\mathbf{1}$ & $\mathrm{R} 01$ & $2 / 2 \mathrm{TT}$ & 5 & 0,5000 \\
$\mathbf{2}$ & $\mathrm{R} 02$ & $2 / 2 \mathrm{TT}$ & 5 & 0,5000 \\
$\mathbf{3}$ & $\mathrm{R} 03$ & $2 / 2 \mathrm{TT}$ & 3 & 0,5000 \\
$\mathbf{4}$ & $\mathrm{R} 04$ & $2 / 2 \mathrm{TT}$ & 5 & 0,5000 \\
$\mathbf{5}$ & R05 & $2 / 2 \mathrm{~T}$ & 8 & 0,5000 \\
$\mathbf{6}$ & R06 & $2 / 2 \mathrm{~T}$ & 8 & 0,5000 \\
$\mathbf{7}$ & R07 & $2 / 2 \mathrm{TT}$ & 6 & 0,5000 \\
$\mathbf{8}$ & R08 & 2/2 TT & 6 & 0,5000 \\
$\mathbf{9}$ & R09 & Jalan satu arah & 4 & 0,3000 \\
\hline
\end{tabular}

Tabel 3. Jumlah Agen pada Ruas Tinjauan Ketika Evakuasi

\begin{tabular}{cccc}
\hline No & $\begin{array}{c}\text { Kode } \\
\text { Jalan }\end{array}$ & $\begin{array}{c}\text { Jumlah Agen } \\
\text { pada Kuisioner }\end{array}$ & $\begin{array}{c}\text { Jumlah Agen } \\
\text { Output NetLogo }\end{array}$ \\
\hline $\mathbf{1}$ & R01 & 542 & 550 \\
$\mathbf{2}$ & R02 & 433 & 459 \\
$\mathbf{3}$ & R03 & 101 & 175 \\
$\mathbf{4}$ & R04 & 108 & 144 \\
$\mathbf{5}$ & R05 & 433 & 472 \\
$\mathbf{6}$ & R06 & 209 & 144 \\
$\mathbf{7}$ & R07 & 209 & 275 \\
$\mathbf{8}$ & R08 & 224 & 181 \\
$\mathbf{9}$ & R09 & 224 & 192 \\
\hline
\end{tabular}

Nilai derajat kejenuhan dihitung berdasarkan analisis dalam pemodelan menggunakan Pedoman Kapasitas Jalan Indonesia (2014). Hasil konversi model dan hitungan kapasitas ruas jalan yang sudah di tinjau dilakukan perhitungan derajat kejenuhan $\left(D_{J}\right)$ (Tabel 4 dan 5). Diagram Perbandingan Derajat Kejenuhan harian dengan Evakuasi Pemodelan dapat dilihat pada Gambar 12.

Waktu tempuh adalah waktu yang digunakan pengguna gedung ketika menempuh pintu keluar melalui ruas-ruas jalan. Waktu tempuh pergerakan pengguna gedung dapat diamati secara manual pada NetLogo. Waktu tempuh pergerakan agen yang diamati pada NetLogo diperoleh rata-rata 14,08 menit atau 844,8 detik untuk 850 ticks. Sehingga waktu 1 detik mewakili 1,01 ticks pada NetLogo. Waktu tempuh yang diperlukah ketika evakuasi pengguna Gedung I lebih lama ketika waktu harian Rekapitulasi waktu di tiap ruas jalan terdapat pada Gambar 13. Kecepatan dapat dihitung setelah waktu tempuh diperoleh. Kecepatan paling tinggi terdapat pada R02 dan R07, R02 memiliki derajat kejenuhan yang tinggi dan sebagai jalur yang banyak dipilih oleh pengguna gedung I. Diagram hubungan kecepatan harian dan evakuasi Pengguna Gedung I terdapat pada Gambar 14.

Tabel 4. Perhitungan Derajat Kejenuhan Evakuasi pada NetLogo

\begin{tabular}{|c|c|c|c|c|c|c|c|c|c|c|}
\hline \multirow[b]{2}{*}{ Kode } & \multirow{2}{*}{$\begin{array}{c}\text { Volume } \\
\text { model } \\
\text { (orang) }\end{array}$} & \multicolumn{3}{|c|}{ Distribusi Mode } & \multicolumn{3}{|c|}{ Kapasitas Angkut } & \multirow{2}{*}{$\begin{array}{c}\text { Volume } \\
\text { Model } \\
\text { (skr / } \\
\text { jam) }\end{array}$} & \multirow{2}{*}{$\begin{array}{c}\text { Kapasitas } \\
\text { jalan } \\
\text { (skr/jam) }\end{array}$} & \multirow[b]{2}{*}{ VCR } \\
\hline & & $\begin{array}{c}\text { MC } \\
(\mathbf{7 3 \%})\end{array}$ & $\begin{array}{c}\text { LV } \\
(\mathbf{3 \%})\end{array}$ & $\begin{array}{c}\text { HV } \\
(0 \%)\end{array}$ & $\begin{array}{l}\text { MC } \\
(0,4)\end{array}$ & $\begin{array}{l}\text { LV } \\
(1)\end{array}$ & $\begin{array}{c}\text { Jalan } \\
\text { Kaki (0) }\end{array}$ & & & \\
\hline R01 & 550 & 401,50 & 18,15 & 0 & 160,60 & 18,15 & 0 & 178,75 & 1118,74 & 0,16 \\
\hline R02 & 459 & 335,07 & 15,15 & 0 & 134,03 & 15,15 & 0 & 149,18 & 1118,74 & 0,13 \\
\hline R03 & 175 & 127,75 & 5,78 & 0 & 51,10 & 5,78 & 0 & 56,88 & 1118,74 & 0,05 \\
\hline R04 & 144 & 105,12 & 4,75 & 0 & 42,05 & 4,75 & 0 & 46,80 & 1118,74 & 0,04 \\
\hline R05 & 472 & 344,56 & 15,58 & 0 & 137,82 & 15,58 & 0 & 153,40 & 1118,74 & 0,14 \\
\hline R06 & 144 & 105,12 & 4,75 & 0 & 42,05 & 4,75 & 0 & 46,80 & 1118,74 & 0,04 \\
\hline R07 & 275 & 200,75 & 9,08 & 0 & 80,30 & 9,08 & 0 & 89,38 & 1118,74 & 0,08 \\
\hline R08 & 181 & 132,13 & 5,97 & 0 & 52,85 & 5,97 & 0 & 58,83 & 1118,74 & 0,05 \\
\hline R09 & 192 & 140,16 & 6,34 & 0 & 56,06 & 6,34 & 0 & $62,4-0$ & 1118,74 & 0,06 \\
\hline
\end{tabular}


Tabel 5. Perhitungan Derajat Kejenuhan Harian Gedung I pada Kuisioner

\begin{tabular}{|c|c|c|c|c|c|c|c|c|c|c|}
\hline \multirow[b]{2}{*}{ Kode } & \multirow[b]{2}{*}{$\begin{array}{c}\text { Volume } \\
\text { model } \\
\text { (orang) }\end{array}$} & \multicolumn{3}{|c|}{ Distribusi Mode } & \multicolumn{3}{|c|}{ Kapasitas Angkut } & \multirow{2}{*}{$\begin{array}{c}\text { Volume } \\
\text { Model } \\
\text { (skr / } \\
\text { jam) }\end{array}$} & \multirow[b]{2}{*}{$\begin{array}{c}\text { Kapasitas } \\
\text { jalan } \\
\text { (skr/jam) }\end{array}$} & \multirow[b]{2}{*}{ VCR } \\
\hline & & $\begin{array}{c}\text { MC } \\
(\mathbf{9 0 \%})\end{array}$ & $\begin{array}{c}\text { LV } \\
(0,04 \\
\%) \\
\end{array}$ & $\begin{array}{c}\text { HV } \\
(0 \%)\end{array}$ & $\begin{array}{c}\text { MC } \\
(\mathbf{0 , 4 )}\end{array}$ & $\begin{array}{r}\mathbf{L V} \\
(\mathbf{1})\end{array}$ & $\begin{array}{c}\text { Jalan } \\
\text { Kaki (0) }\end{array}$ & & & \\
\hline R01 & 586 & 527,14 & 23,43 & 0 & 210,86 & 23,43 & 0 & 234,29 & 1312,84 & 0,18 \\
\hline R02 & 507 & 456,43 & 20,29 & 0 & 182,57 & 20,29 & 0 & 202,86 & 1312,84 & 0,15 \\
\hline R03 & 64 & 57,86 & 2,57 & 0 & 23,14 & 2,57 & 0 & 25,71 & 1312,84 & 0,02 \\
\hline R04 & 79 & 70,71 & 3,14 & 0 & 28,29 & 3,14 & 0 & 31,43 & 1312,84 & 0,02 \\
\hline R05 & 507 & 456,43 & 20,29 & 0 & 182,57 & 20,29 & 0 & 202,86 & 1440,57 & 0,14 \\
\hline R06 & 286 & 257,14 & 11,43 & 0 & 102,86 & 11,43 & 0 & 114,29 & 1440,57 & 0,08 \\
\hline R07 & 143 & 128,57 & 5,71 & 0 & 51,43 & 5,71 & 0 & 57,14 & 2039,59 & 0,03 \\
\hline R08 & 221 & 199,29 & 8,86 & 0 & 79,71 & 8,86 & 0 & 88,57 & 2039,59 & 0,04 \\
\hline R09 & 586 & 527,14 & 23,43 & 0 & 210,86 & 23,43 & 0 & 234,29 & 1312,84 & 0,18 \\
\hline
\end{tabular}

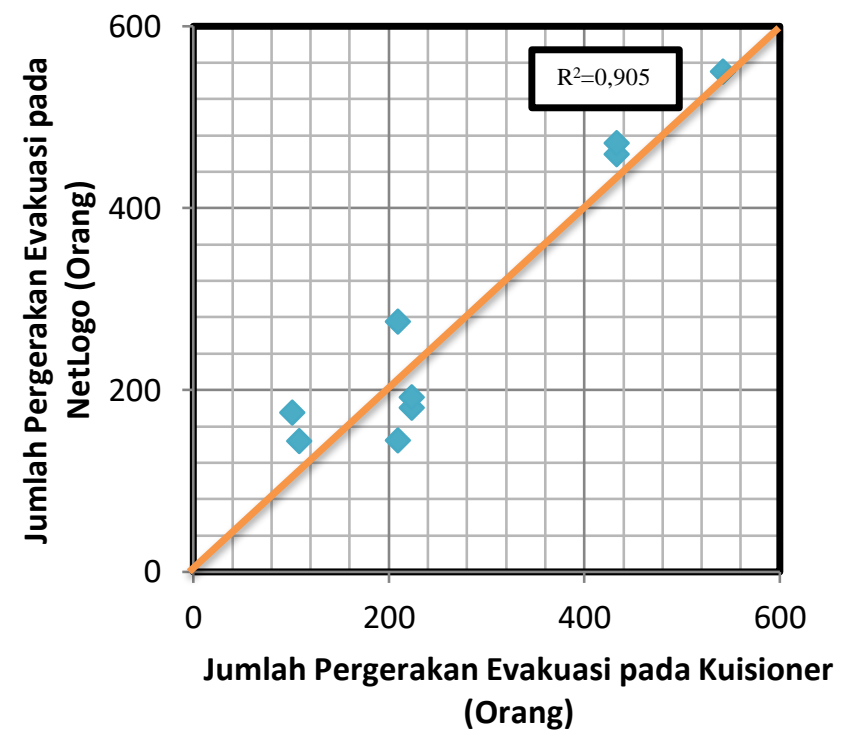

Gambar 11. Grafik Regresi Linier Menggambarkan Kedekatan Hasil Responden dan Simulasi NetLogo

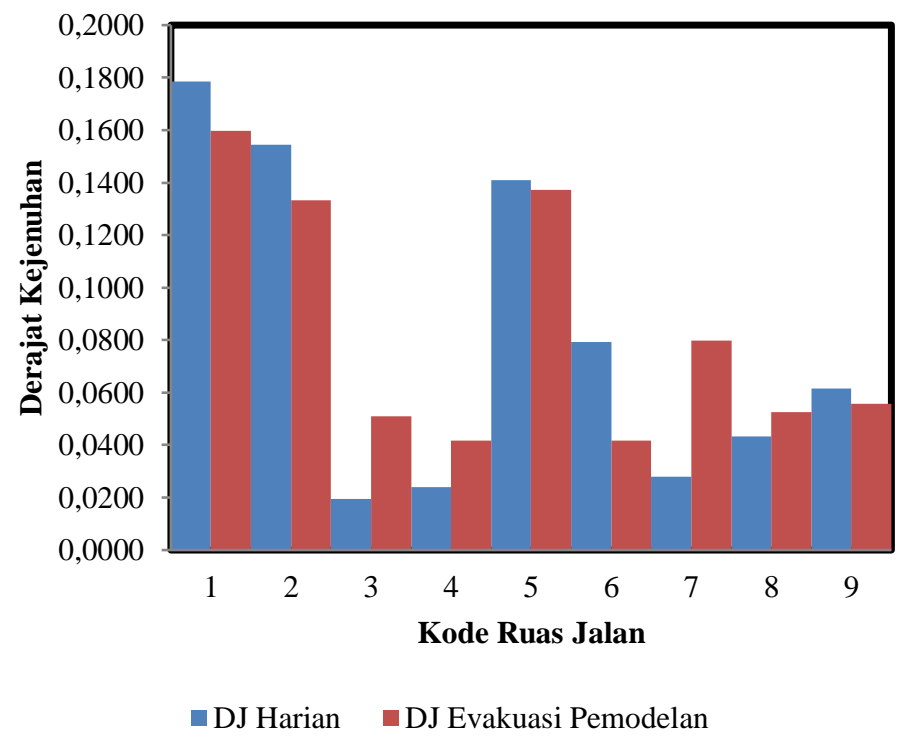

Gambar 12. Diagram Perbandingan Derajat Kejenuhan Harian dan Evakuasi Pemodelan pada Gedung I Universitas Bengkulu 


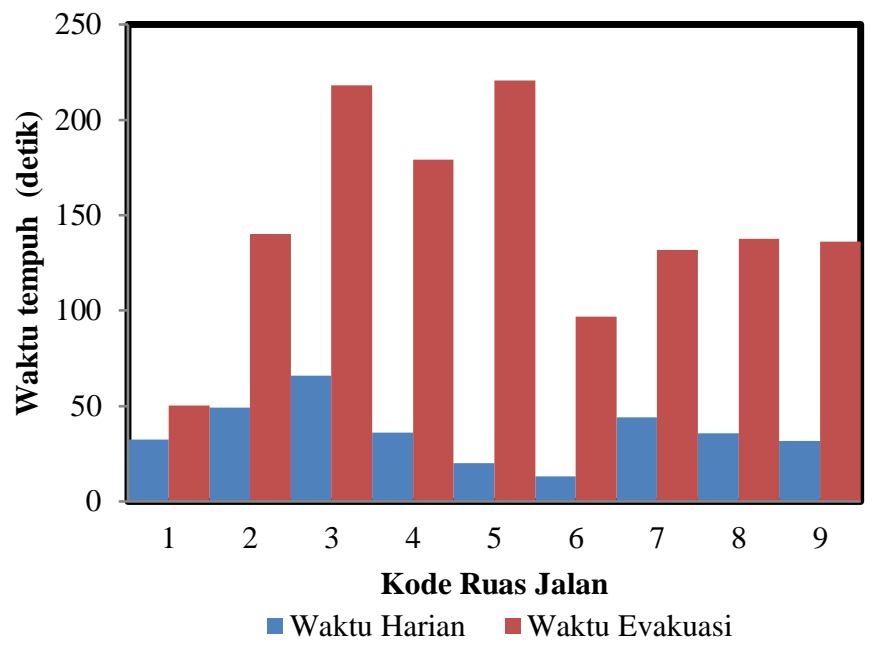

Gambar 13. Diagram Perbandingan Waktu Tempuh Harian dan Evakuasi Pemodelan

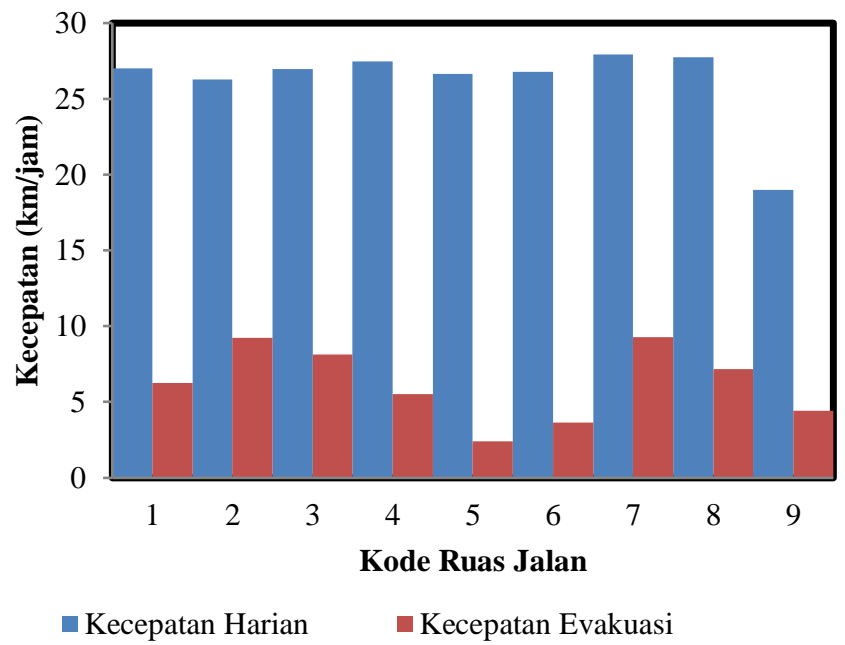

Gambar 14. Diagram Perbandingan Kecepatan Harian dan Evakuasi Pemodelan

\section{KESIMPULAN}

1. Populasi agent pada Gedung I Bengkulu adalah sebanyak 650 orang dan jaringan jalan ynag ditinjau adalah jaringan jalan lokal Universitas Bengkulu

2. Berdasarkan simulasi, NetLogo dapat memodelkan proses evakuasi dengan perbandingan terhadap kuesioner sebesar $\mathrm{R}^{2}=0,905$ atau $90,5 \%$.

3. Dari hasil kuesioner persentase alternatif rute yang telah dipilih oleh responden yaitu Rute 1 sebesar $27,8 \%$, Rute 2 sebesar $34,4 \%$, Rute 3 sebesar 16,7\%, Rute 4 sebesar 21,1\%. Hasil kuesioner menunjukkan bahwa responden banyak memilih rute alternatif 2 dengan persentase 34,4\%. Responden (orang) lebih memilih rute Alternatif 2 dikarenakan rute tersebut merupakan jalur yang biasa dilalui jika menuju pintu keluar universitas dan mudah dijangkau oleh responden. Selain itu tingkat kualitas jalan lebih lebar dan tidak terlalu jauh. Rute 2 merupakan jarak yang cukup panjang tetapi memiliki lebar jalan yang lebih memadai daripada rute lainnya. Selain itu, melalui rute 2, sangat efektif untuk menjauhi arah datangnya gelombang sesuai dengan arah pintu keluar. Pada rute 1, 3, dan 4 responden akan menuju pintu keluar melalui R06 dan R07, sehingga mengindikasikan bahwa pintu keluar pada jalur tersebut akan mengalami kepadatan walaupun jarak tempuh lebih pendek dari rute 2 .

4. Nilai derajat kejenuhan $\left(D_{J}\right)$ terbesar pada titik masuk ke ruas jaringan jalan R01, R02, dan R05. Terdapat 6 ruas jalan yang memiliki angka kejenuhan 0,0418 sampai 0,0799 yaitu R03, R04, R06, R07, R08, R09. Dua ruas jalan lainnya memiliki angka derajat kejenuhan 0,1598 (R01), 0,1333 (R02), dan 0,1371 (R05). Keseluruhan ruas jalan masih dalam rentang derajat kejenuhan < 0,5. Ditinjau menurut peraturan PKJI 2014 Ruas jalan masih memadai dalam pergerakan evakuasi. 


\section{UCAPAN TERIMA KASIH}

Penelitian ini banyak yang membantu penulis, sehingga penulis mengucapkan terima kasih kepada pihak Gedung I Universitas Bengkulu yang telah memberikan izin untuk melaksanakan penelitian di Gedung I dan menyelesaikan penelitian dengan baik.

\section{DAFTAR PUSTAKA}

[1] Bonabeau, E. 2006. Agent-Based Modeling: Methods and Techniques for Simulating Human Systems Dalam Proceedings of National Academy of Sciences of the United States of America (hal 7280 - 7287).

[2] Gaffar, E.Z. 2007. Pemetaan dan Kajian Bencana Tsunami Daerah Kota Bengkulu. Proseding Seminar Geoteknologi Kontribusi Ilmu Kebumian Dalam Pembangunan Berkelanjutan Bandung 3 Desember2007, ISBN: 978-979-799-255-5, Bandung, Puslit Geoteknologi - LIPI.

[3] Harlan, J. 2018. Analisis Regresi Linier. Depok, Gunadarma

[4] Hardiansyah, Muthohar, I., Priyanto, S., dan Suprama, L.B. 2016. Konsep Pemodelan Transportasi untuk Evakuasi Bencana. Jurnal Transportasi Forum Studi Transportasi Antar-Perguruan Tinggi.

[5] Kolinug, Lendy A., Sendow, T.K., Jansen, F., dan Manoppo, M.R.E. 2013. Analisa Kinerja Jaringan Jalan dalam Kampus Universitas Sam Ratulangi. Jurnal Sipil Statik Vol.1 No.2, Januari 2013 (119-127), Manado, Universitas Sam Ratulangi.

[6] Maryuliana, Subroto, I.M.I., Haviana, S.F.C. 2016. Sistem Informasi Angket Pengukuran Skala Kebutuhan Materi Pembelajaran Tambahan sebagai Pendukung Pengambilan Keputusan di Sekolah Menengah Atas Mengunakan Skala Likert. Volume 1 No. 2 Oktober 2016, Jurnal Transistor Elektro dan Informatika TRANSISTOR EI), Teknik Informatika, Universitas Islam Sultan Agung.

[7] Manual Kapasitas Jalan Indonesia (MKJI) 1997. Departemen Pekerjaan Umum Direktorat Jendral Bina Marga.

[8] Natawidjaya, D.H. 2007. Tectonic Setting Indonesia dan Pemodelan Sumber Gempa dan Tsunami. Pelatihan Pemodelan Run-Up Tsunami, Ristek, 20-24 Agustus 2007, Geoteknologi - LIPI.

[9] Nur, A.M. 2010. Gempa Bumi, Tsunami dan Mitigasinya. Volume 7 No. 1 Januari 2010, Kebumen, Balai Informasi dan Konservasi Kebumian Karangsambung - LIPI.

[10] Susiloningtyas, D., Boer, M., Adrianto, L., Yulianda, F. 2015. Pemodelan Berbasis Agen (ABM) untuk Pengelolaan Aktivitas Migrasi Musiman Nelayan Andon Cumi-cumi di Pulau Salura. Volume 10 No. 16 Juni 2015, Jakarta, Indonesia.

[11] Pedoman Kapasitas Jalan Indonesia (PKJI) 2014. Departemen Pekerjaan Umum Direktorat Jendral Bina Marga.

[12] Spahn, H., Hoppe, M., Usdianto, B., dan Vidiarina,H. 2010. Perencanaan untuk Evakuasi Tsunami: Panduan untuk Pemerintah Daerah dan Pemangku Kepentingan Lain di Wilayah Pesisir Indonesia. Kerjasama Indonesia - Jerman untuk Sistem Peringatan Dini Tsunami (GITNEWS) Peningkatan Kapasitas Komunitas Lokal.

[13] Sugiyono. 2014. Metode Penelitian Pendidikan Pendekatan Kuantitatif, Kualitatif, dan R\&D. Bandung: Alfabeta.

[14] Tamin, O.Z. 2000. Perencanaan \& Pemodelan Transportasi Edisi Kedua. Bandung, Institut Teknologi Bandung. 